\title{
The Unforgettable Byron White
}

\author{
Edward M. Kennedy ${ }^{\dagger}$
}

I first met Byron White in the late fall of 1959. I was twenty-seven, and I was making my first trip to a group of Western states to help lay the groundwork for my brother Jack's presidential campaign in 1960. Jack had first met Byron briefly in England in the 1930s, when Byron was a Rhodes Scholar at Oxford and my father was the U.S. Ambassador in London. Later, by a remarkable coincidence, Jack and Byron came to know each other well when they served together in the Navy for a month on a base in the South Pacific during World War II. I knew how much Jack liked and respected Byron, and how pleased Jack was when Byron agreed in 1959 to be my brother's Colorado chairman for the coming presidential campaign.

In a period of six weeks that fall, I went to Montana, Idaho, Utah, Arizona, New Mexico, and then Colorado. Byron met me at the Denver airport and brought me to his law office, where I met several of his colleagues and began making a series of telephone calls. He said that the next morning we would begin driving around the state to line up support for Jack, and we did.

On the first day, we went to Pueblo and met with a railroad man who was a Democratic Party leader in the area. We found him very receptive and responsive. He said that he liked Jack, but that my brother was not well-known in the state. He thought Jack could obtain strong early support from working families in Pueblo and use that support to win votes in other parts of the state.

We continued on the trip, and at each stop, often for a breakfast or lunch, we'd get together with 25,30 , or 35 local Democratic leaders. I was impressed that so many of them attended our sessions, and I quickly understood why-they all wanted to meet Byron.

Every night, we shared a room in a local motel. Byron would order a Tbone steak, a baked potato, and a Coors beer. He'd read for an hour or two and turn out the light. At 6:30 or 7:00 the next morning, he'd wake me up doing his push-ups, and we'd be off for another round of meetings.

$\dagger$ United States Senator from Massachusetts. 
On the last day of our trip, Byron said, "Ted, why don't you fly the redeye back East, and we'll go up to ski. There's new snow on the ground." We had a wonderful time skiing together. At the end of the day, we stopped by his home for an hour or so. We went on to the airport, and I flew back to Washington.

The next morning, I walked into a meeting with Jack, my brother Bobby, Larry O'Brien, and several others. They all wanted to hear how Jack was doing in the states I'd visited. Jack took one look at me, though, and the first words out of his mouth were, "Have you been skiing with Byron White in Colorado?"

"Only for a day," I said, and everybody roared with laughter. I could have given the Gettysburg Address and nobody would have paid attention. As the laughter died down, Jack telephoned Byron, who reassured him that we had actually worked very hard during the trip. After that, the group paid somewhat more attention to my presentation about the opportunities we'd have and the difficulties we'd face in the coming campaign.

I saw Byron on many other occasions during the presidential campaign, his service as Deputy Attorney General under Bobby in the Justice Department, and his years on the Supreme Court. But those six days with Byron in 1959 have always had a very special place in my memory. His great abilities were obvious, and so were the inner reserve and the steel that were part of his soul. None of us who knew him will ever forget him. 